\title{
Numerical simulation of pore pressure changes in levee under flood conditions
}

\author{
Jacek Stanisz ${ }^{1 *}$, Aleksandra Borecka $^{1}$, Zenon Pilecki ${ }^{2}$ and Robert Kaczmarczyk ${ }^{1}$ \\ ${ }^{1}$ AGH University of Science and Technology, 30-059 Krakow, Poland \\ ${ }^{2}$ Mineral and Energy Economy Research Institute, Polish Academy of Sciences, 31-261 Krakow, \\ Poland
}

\begin{abstract}
The article discusses the potential for using numerical simulation to assess the development of deformation and pore pressure changes in a levee as a result of the increase and decrease of the flood wave. The simulation made in FLAC 2D did not take into account the filter-erosion deformation associated with seepage in the levee. The simulations were carried out for a field experimental storage consisting of two combined levees, which was constructed with the help of homogeneous cohesive materials with different filtration coefficients. Calculated and measured pore pressure changes were analysed at 4 monitoring points. The water level was increased to $4 \mathrm{~m}$ in 96 hours and decreased in 120 hours. The characteristics of the calculated and measured pore pressure changes over time were similar. The maximum values of the calculated and measured pore pressure were almost identical. The only differences were the greater delay of the experimental levee response to changes in water level increase compared to the response of the numerical model. These differences were probably related to filtering-erosion effects during seepage in the levee.
\end{abstract}

\section{Introduction}

Levees are a basic element of the flood protection system [1]. In Poland their total length is about $8500.0 \mathrm{~km}$. Nearly $60 \%$ of them are over 40 years old, only $20 \%$ have been in use for 20 years [2].

Deformation of the levee results from the hydraulic pressure of water, water filtering through the levee and its subsoil, and the hydrating and drying of the levee material [3]. This process is intensified under the influence of an increased level of water during a flood. Under conditions of change in water pressure, the development of the deformation process often leads to the failure of the levee [4-6].

The article presents the results of numerical simulation of the behaviour of the levee under an increase and decrease of the hydraulic pressure for water levels up to $4 \mathrm{~m}$ in height. We analysed the pore pressure changes in the levee. The results of numerical calculations were compared with the results of field measurements inside of an experimental water storage facility, which was built under the ISMOP Project (IT System

\footnotetext{
*Corresponding author: jstanisz@agh.edu.pl
} 
of Levee Monitoring) [7-8]. The study is based also on results a few experiments conducted under the project [9-12].

\section{Characteristics of the research area}

The research area is located in Czernichów village near the Vistula river in southern Poland, about $20 \mathrm{~km}$ in west of Cracow. The water storage of $208 \times 58 \times 4.5 \mathrm{~m}$ ( $\mathrm{L} \mathrm{x} \mathrm{W} \mathrm{x} \mathrm{H})$ forms two sections of levees joined to each other (Fig. 1). The volume of the structure is about $28.500 \mathrm{~m}^{3}$. The levee slopes have variable inclination - the waterside is $1: 2$ and 1:2.5, and the landside is $1: 2$.

The levee on the eastern side was built of silty clay, and on the west side of silty sand with filtration coefficients of $1.83 \cdot 10^{-5}$ and $5.24 \cdot 10^{-5} \mathrm{~m} / \mathrm{s}$ respectively. The subsoil is formed of silty clay and clayey sand, sands and gravels. Ground-water conditions were identified by boreholes and dynamic and static sounding [13]. The levee in contact with subsoil was isolated by impermeable bentomate.

In the field measurements, the influence of the increase and decrease of the water level on the levee's behaviour was simulated [14-16]. The changes of water pressure were measured by pore pressure sensors.
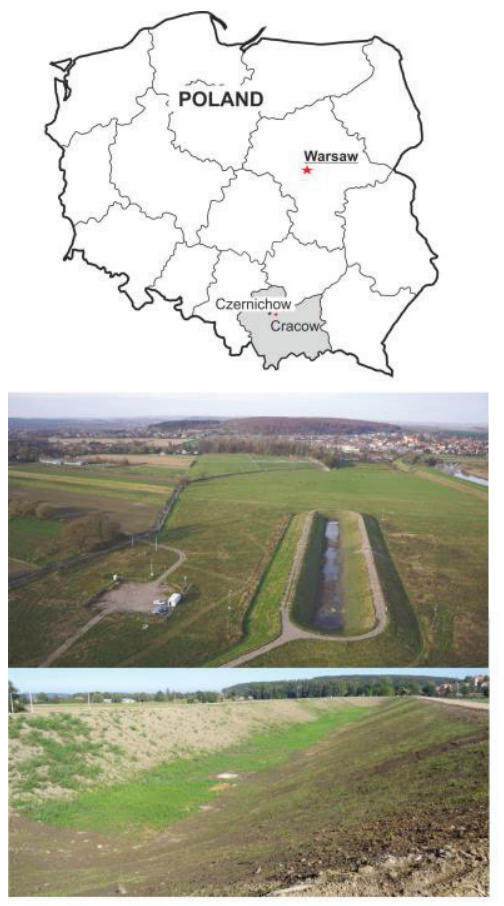

Legend

- OM-1 Mechanical drilling

- OR-1 Core drilling

O-1 Manually drilling

- D4 Dynamic sounding

- C1 Static sounding CPTU

- A Monitoring point

IV Monitoring profile
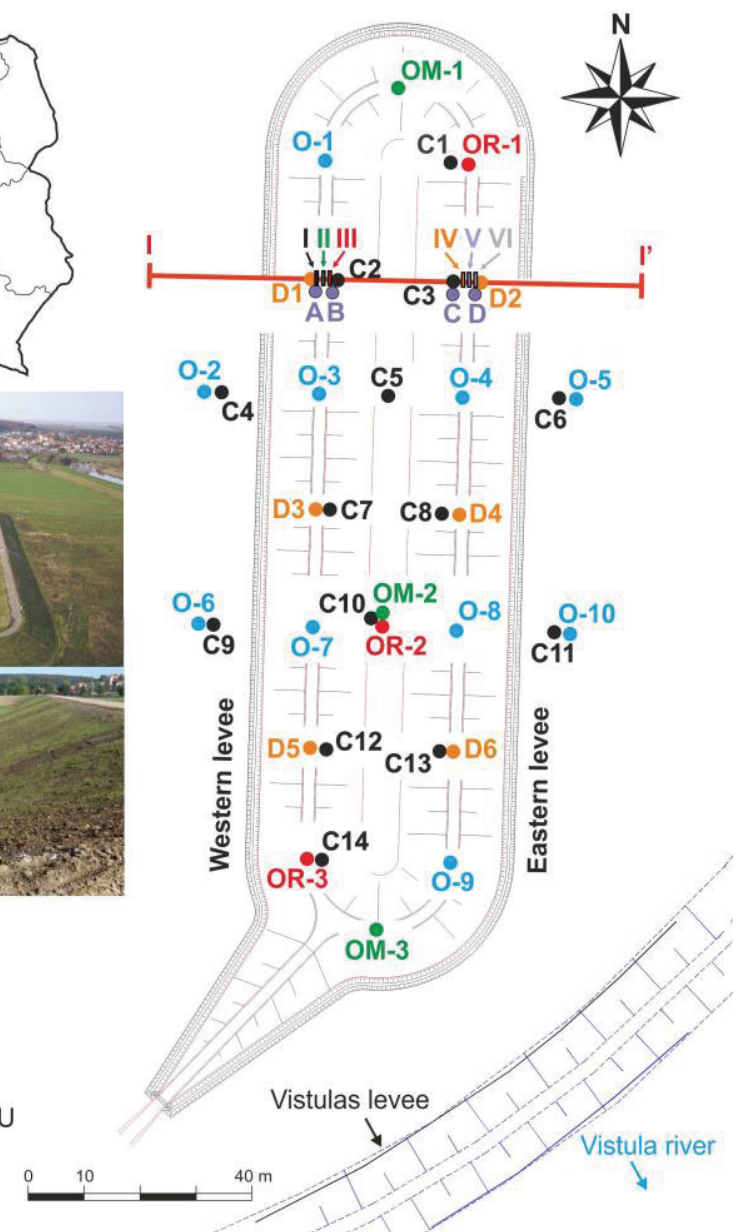

Fig. 1. Location and plan of the experimental water storage facility [14]. 


\section{Methodology}

\subsection{Calculation scheme}

A schematic diagram of the calculation procedure is shown in Figure 2. In calculations we assumed a continuous increase of water level up to $4 \mathrm{~m}$ during 96 hours and decrease within 120 hours. The numerical simulations were made in plane state of strain with the help of FLAC 2D v. 7.0 code. The pore pressure changes were analysed in the selected cross section I - I' and in 4 monitoring points located in the lower part of the levees, shown in Figure 1. Points A and B were placed in an levee on the eastern side of the water storage facility and points $\mathrm{C}$ and $\mathrm{D}$ in an levee on the western side.

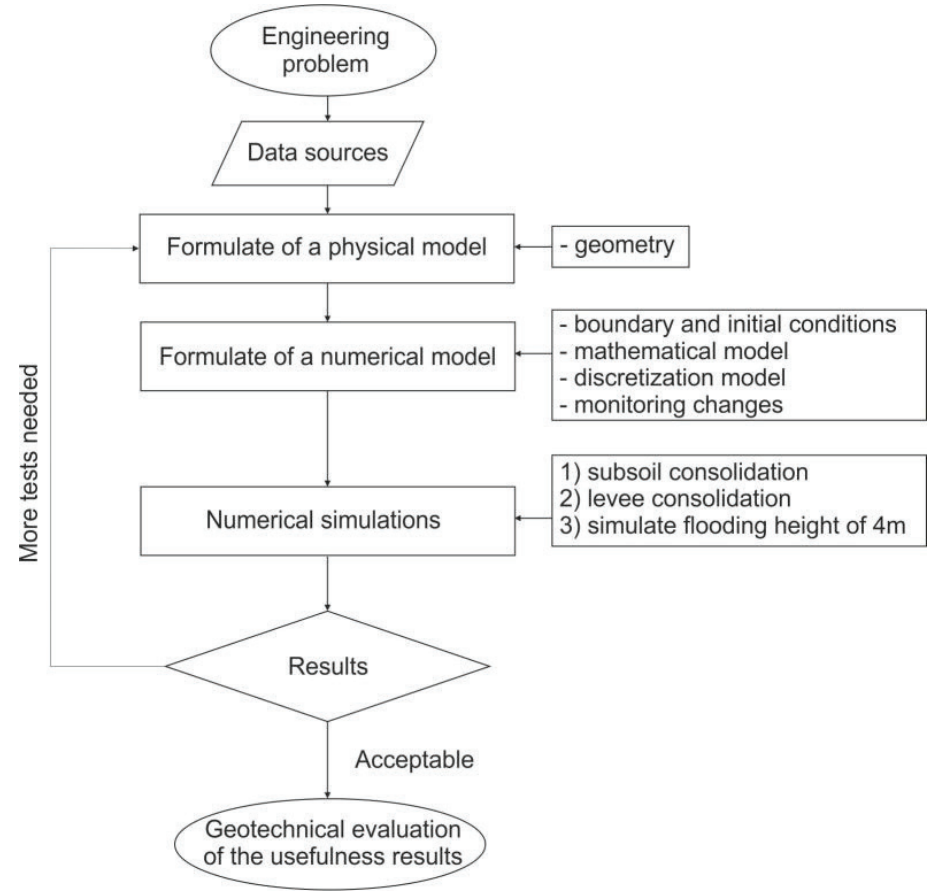

Fig. 2. A schematic diagram of a numerical simulation [17-18].

\subsection{Physical model}

The physical model was prepared along cross-section I-I' running through the central part of the experimental storage (Fig. 3). It is assumed that the vertical frame is $11 \mathrm{~m}$ high and the horizontal frame is $90 \mathrm{~m}$ long. There are 6 geotechnical layers with material properties listed in Table 1. The first layer corresponds to the levee material from the eastern or western side of the experimental storage. The remaining 5 layers are located in the subsoil of the storage. 


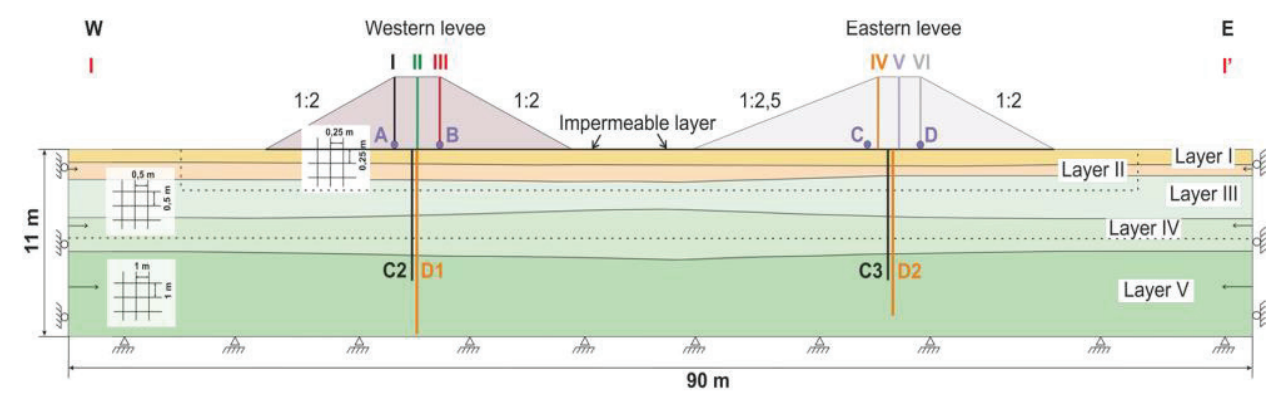

Fig. 3. Physical model of the water storage with subsoil along cross-section I-I'.

Table 1. Material constants of levees and subsoil layers.

\begin{tabular}{|c|c|c|c|c|c|c|}
\hline $\begin{array}{c}\text { Number } \\
\text { of layer }\end{array}$ & $\begin{array}{c}\text { Bulk } \\
\text { density } \\
{\left[\mathbf{M g} / \mathbf{m}^{3}\right]}\end{array}$ & Cohesion & $\begin{array}{c}\text { Angle of } \\
\text { internal } \\
\text { friction } \\
{[\mathbf{d e g}]}\end{array}$ & $\begin{array}{c}\text { Bulk } \\
\text { modulus } \\
{[\mathbf{k P a}]}\end{array}$ & $\begin{array}{c}\text { Shear } \\
\text { modulus }\end{array}$ & $\begin{array}{c}\text { Filtration } \\
\text { coefficient } \\
{[\mathrm{kPa}]}\end{array}$ \\
\hline $\begin{array}{c}\text { Eastern } \\
\text { levee }\end{array}$ & 1.9 & 12.5 & 30.04 & $8.53 \mathrm{e}^{3}$ & $3.27 \mathrm{e}^{3}$ & $1.83 \mathrm{e}^{-5}$ \\
\hline $\begin{array}{c}\text { Western } \\
\text { levee }\end{array}$ & 1.96 & 15.43 & 35.2 & $7.25 \mathrm{e}^{3}$ & $3.35 \mathrm{e}^{3}$ & $5.24 \mathrm{e}^{-5}$ \\
\hline I & 2.1 & 10.3 & 32.9 & $7.25 \mathrm{e}^{3}$ & $3.43 \mathrm{e}^{3}$ & $1.52 \mathrm{e}^{-5}$ \\
\hline II & 1.89 & 13.7 & 22.5 & $16.2 \mathrm{e}^{3}$ & $6.63 \mathrm{e}^{3}$ & $1.35 \mathrm{e}^{-5}$ \\
\hline III & 1.85 & 9.5 & 35.4 & $16.2 \mathrm{e}^{5}$ & $6.63 \mathrm{e}^{4}$ & $1.32 \mathrm{e}^{-6}$ \\
\hline IV & 1.9 & 9.3 & 39.4 & $16.2 \mathrm{e}^{5}$ & $6.63 \mathrm{e}^{4}$ & $1.32 \mathrm{e}^{-5}$ \\
\hline V & 2.05 & 7.2 & 40.1 & $36.8 \mathrm{e}^{5}$ & $21.8 \mathrm{e}^{4}$ & $5.5 \mathrm{e}^{-5}$ \\
\hline
\end{tabular}

\subsection{Calculation model}

In calculations, we assumed a elastic-plastic mechanical model with use of Mohr-Coulomb strength criterion. Hydrostatic pressure was applied on the waterside of the levees. Water flow was allowed on the landside of the levees. The model was discretised with a regular grid of $0.25 \mathrm{~m}$ for the levee, $0.5 \mathrm{~m}$ for layer I-III and $1 \mathrm{~m}$ for layers IV and V. The effect of the increase in water level was analysed: (1) up to $2 \mathrm{~m}$ in 48 hours, (2) up to $4 \mathrm{~m}$ in 96 hours and (3) with return to the initial situation in 120 hours.

\section{Results and analysis}

The results of numerical simulations in the form of isoline changes of pore pressure, shear stress and horizontal displacement are shown in Figures 4-6.

The increase of the water level up to $2 \mathrm{~m}$ resulted in an increase of pore pressure up to $20 \mathrm{kPa}$ at the bottom part of the levee (Fig. 4a). For the assumed duration of waterlogging, the shear stresses reached values of -15 to $20 \mathrm{kPa}$ on the landside of the experimental storage (Fig. 4b). The levee began to deform and the horizontal displacement reached $7 \mathrm{~mm}$ (Fig. 4c). In this case, the maximum water flow velocity in the levees was $0.33 \mathrm{~m} / \mathrm{d}$. 

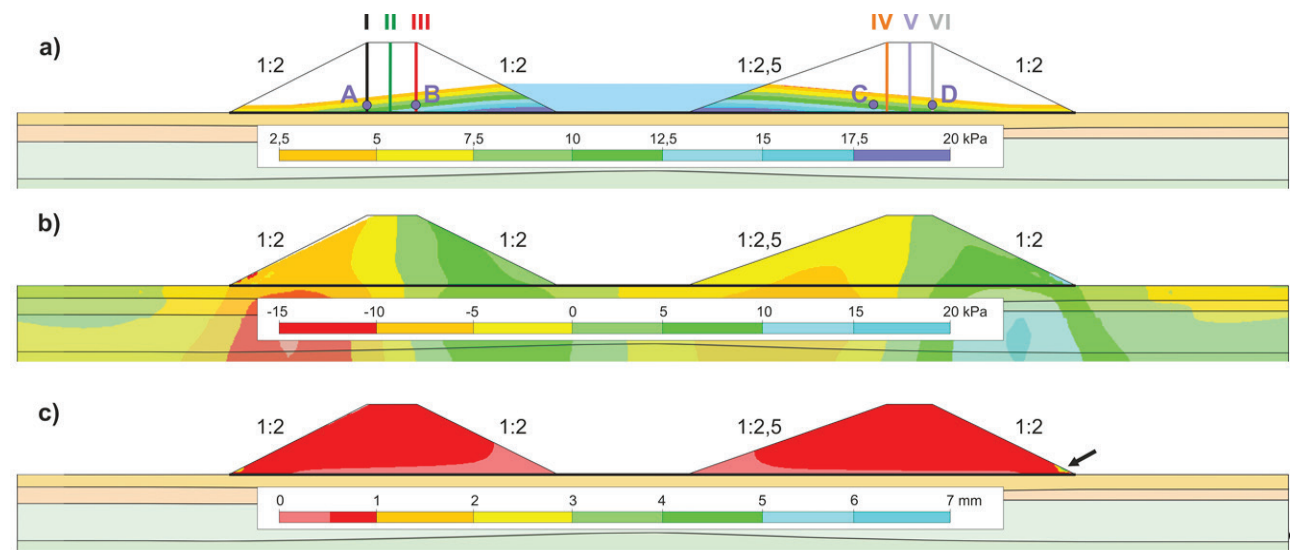

Fig. 4. Pore pressure field (a), shear stress (b) and horizontal displacement (c) inside the levee for an increase in water level to a height of $2 \mathrm{~m}$. The black arrow indicates the zone of maximum displacement $(7 \mathrm{~mm})$.

In these conditions, the water level increased to $4 \mathrm{~m}$, the pore pressure increased to 40 $\mathrm{kPa}$ and the deformation process increased in the bottom part of the levees (Fig. 5a). In the levees a considerable decrease in pore pressure value to several $\mathrm{kPa}$ was observed, presumably due to an increase in the velocity of water flow to $3.5 \mathrm{~m} / \mathrm{d}$. On the landside of the levees, horizontal displacement reached a value of $14 \mathrm{~mm}$ (Fig. 5c). In the surface part of the waterside of the levees, an increase in shear stress of up to $40 \mathrm{kPa}$ was observed (Fig. $5 b)$.
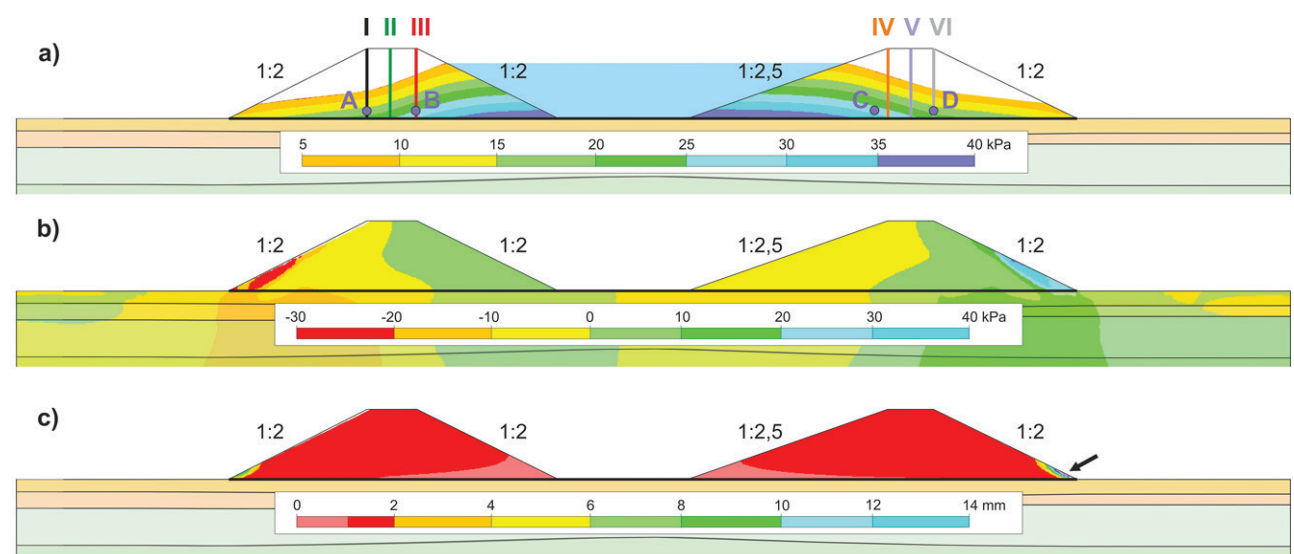

Fig. 5. Pore pressure field (a), shear stress (b) and horizontal displacement (c) inside the levee for an increase in water level to a height of $4 \mathrm{~m}$. The black arrow indicates the zone of maximum displacement (14 mm).

As a result of a water level decrease to $1 \mathrm{~m}$, the pore pressure reached a value of $18 \mathrm{kPa}$ (Fig. 6a). Under these conditions, the maximum displacement achieved was $3 \mathrm{~mm}$ (Fig. 6c), and the water flow velocity inside the levees decreased to about $0.13 \mathrm{~m} / \mathrm{d}$ (Fig. 6b). 

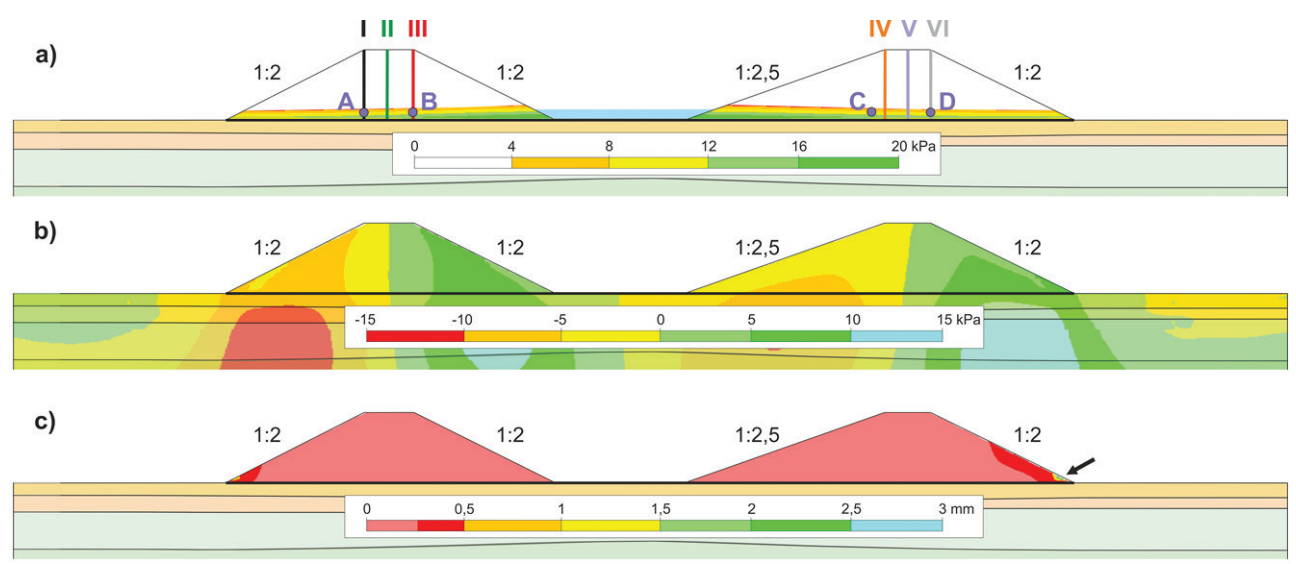

Fig. 6. Pore pressure field (a), shear stress (b) and horizontal displacement (c) inside the levee for a decrease in water level to a height of $1 \mathrm{~m}$. The black arrow indicates the zone of maximum displacement (3 mm).

In general, the pore pressure in the numerical model increases and decreases approximately in accordance with changes in water level (Fig. 7). By comparing the pore pressure changes at the four monitoring points $\mathrm{A}, \mathrm{B}, \mathrm{C}$ and $\mathrm{D}$ in the numerical model and in the field experimental storage, we observed that the characteristics of these changes is similar. The maximum values of pore pressure calculated and measured are almost identical. The differences only occurred with the late response of the experimental levee compared to the response of the levee in the numerical model (Fig. 7). Presumably, these differences are related to filter-erosion effects during water flow through the experimental levee. Under conditions of water level decrease, the calculated and measured pore pressure values were similar at all monitoring points.

It should be emphasised that the short time of increase and decrease of the water level limited the development of deformation in the levee. Under the conditions of the field experiment, the asymmetric levee built of silty sand was more susceptible to deformation, with higher pore pressure values of approximately $5-7 \mathrm{kPa}$ (Fig. 8).

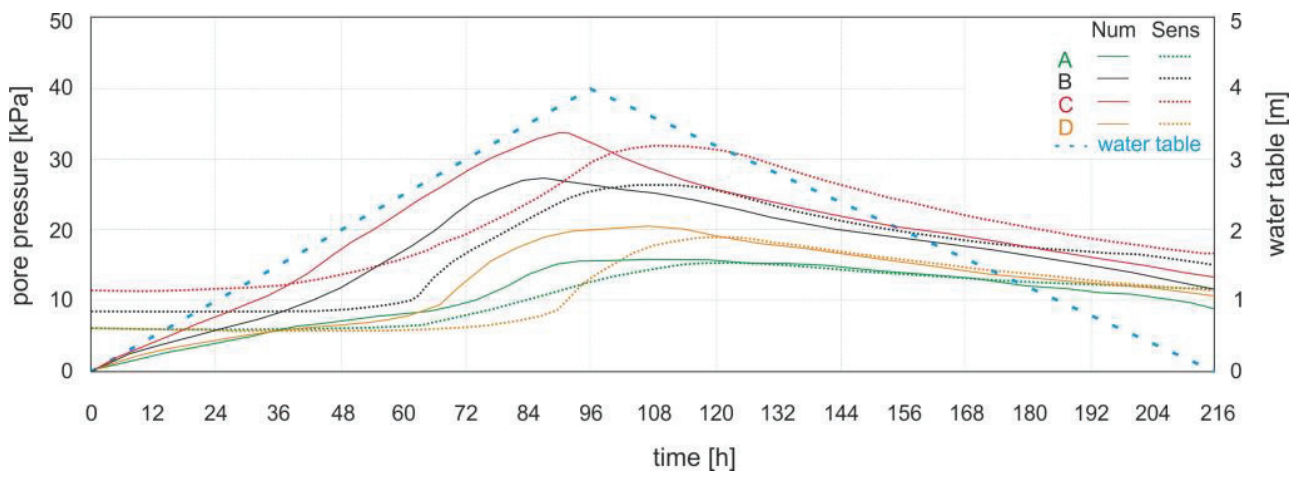

Fig. 7. The changes of pore pressure at four monitoring points (A-D) during a $4 \mathrm{~m}$ increase in the height of the water level in the numerical model (Num) and field experiment (Sens). 

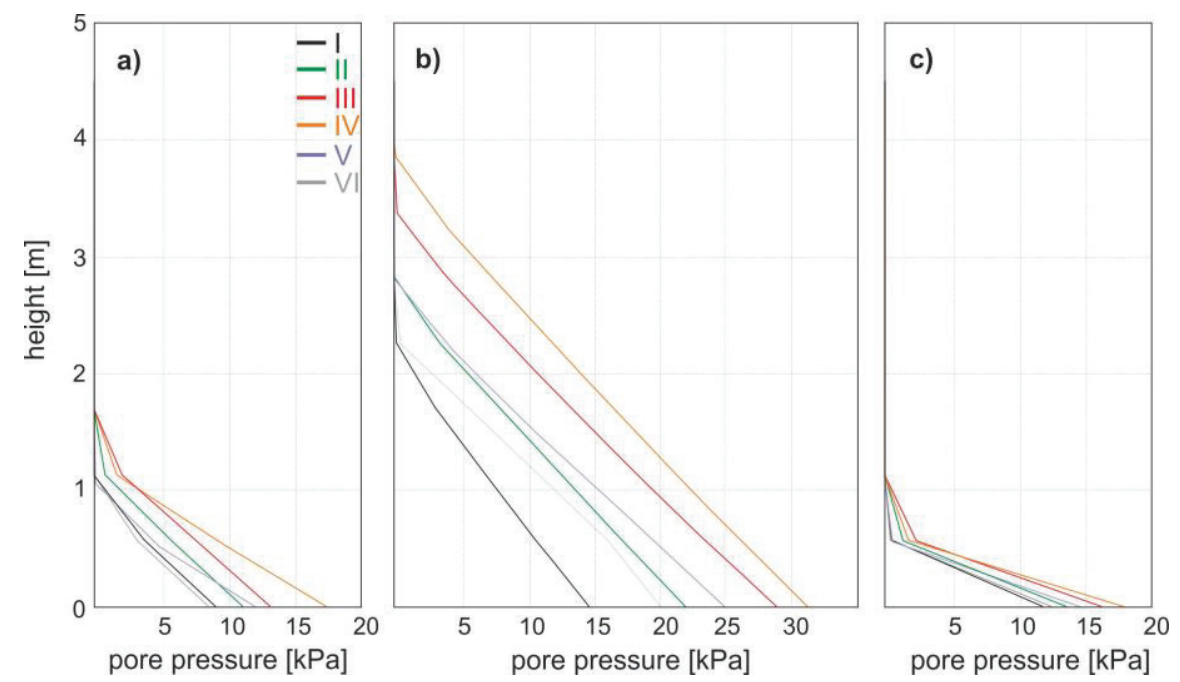

Fig. 8. Changes of pore pressure in sections I-VI for an increase in water level up to $2 \mathrm{~m}$ (a) $4 \mathrm{~m}$ (b) and its decrease to $1 \mathrm{~m}(\mathrm{c})$ in field measurements.

\section{Conclusions}

The results of a numerical simulation of the influence of hydraulic pressure on the levee allow us to draw the following conclusions:

1. Under conditions of water level increase, the changes of pore pressure in time and its maximum values in the numerical model of the levee and in the field experimental levee are similar. The differences in behaviour of both levees only occurred with the late response of the experimental levee comparing to the response of the levee in the numerical model. Presumably, these differences are related to filter-erosion effects during water flow through the experimental levee.

2. Under conditions of water level decrease, calculated and measured pore pressure changes in time were similar in all monitoring points.

3. For the increase in water level up to $4 \mathrm{~m}$ height in the numerical model, the greatest displacements occurred in the bottom part of the levee on its landside. Water outflow was observed on the surface of this slope in the field experimental levee. The calculated shear stress was $30-40 \mathrm{kPa}$. Horizontal displacement was increased to 14 $\mathrm{mm}$.

4. The results obtained show the significant influence of hydraulic pressure caused by the increase in water level on pore pressure changes and possible development of the levee damage process [19].

The research presented in this paper was supported by the National Centre for Research and Development (NCBiR) under Grant No. PBS1/B9/18/2013

\section{References}

1. J. Stanisz, A. Borecka, A. Leśniak, K. Zieliński, Wybrane systemy monitorujace obwałowania przeciwpowodziowe, Przegląd Geologiczny 62, 699-703 (2014)

2. J. Filaber, B. Kosowski, A. Borecka, Flood protection in crisis management system (Texter Warsaw, 2016) 
3. A. J. Lobbestael, A. Athanasopoulos-Zekkos, J. Colley, Math. Probl. Eng., 2013, 1-13 (2013) doi 10.1155/2013/893602

4. Z. Pilecki, Rozpoznanie metoda sejsmiczna stanu podłoża obwałowań przeciwpowodziowych, Bezpieczeństwo Pracy i Ochrona Środowiska w Górnictwie Miesięcznik Wyższego Urzędu Górniczego 5, 37-39 (2004)

5. U. el Shamy, F. Aydin, J. Geotech. Geoenviron. 134, 9, 1385-1398 (2008) doi 10.1061/(ASCE)1090-0241(2008)134:9(1385)

6. T. Zydroń, A. Gruchot, Wpływ opadu deszczu $i$ erozji bocznej na stateczność na przykładzie osuwiska w Bieśniku (Beskid Niski). Acta Scientiarum Polonorum, Seria Architectura 15, 3, 149-161 (2016)

7. J. Stanisz, K. Korzec, A. Borecka, ISMOP Project (IT System of Levee Monitoring) as an example of integrated monitoring of levee, Geology, Geophysics \& Environmental 41, 137-139 (2015)

8. A. Borecka, J. Stanisz, K. Sekuła, A. Leśniak, Smart levee in Poland, Abstract Book $3^{\text {th }}$ FLOODRisk, 3, 258 (2016)

9. B. Bukowska-Belniak, M. Dwornik, A. Pięta, A. Leśniak, A 2D model of temperature changes in experimental embankment, Measurement, Automation, Monitoring 61, 6, 233-236 (2015)

10. K. Krawiec, B. Bukowska-Belniak, A. Leśniak, D. Kessler, E3S Web Conf. 7 (2016) doi: $10.1051 / \mathrm{e} 3$ sconf $/ 20160703018$

11. M. Dwornik, K. Krawiec, A. Franczyk, A. Leśniak, E3S Web Conf. 7 (2016) doi: 10.1051/e3sconf/20160703018

12. A. Pięta, K. Krawiec, Procedia Comput. Sci. 51, 2668-2677 (2015) doi: 10.1016/j.procs.2015.05.377

13. J. Mościcki, G. Bania, M. Ćwiklik, A. Borecka, DC resisitivity studies of shallow geology in the vicinity of Vistula river flood bank in Czernichów village (near Kraków in Poland), Studia Geotechnica et Mechanica 36, 1, 63-70 (2014)

14. M. Chuchro, A. Franczyk, B. Bukowska-Belniak, A. Leśniak, Reducing flood risk using computer system for monitoring river embankments, Environmental Protection and Natural Resources 28, 3, 73, 11-16 (2017)

15. A. Pięta, M. Chuchro, M. Lupa, A. Piórkowski, A. Leśniak, Lect. Notes. Comput. SC. 8838, 514-525 (2014) doi: 10.1007/978-3-662-45237-0_47

16. A. Franczyk, M. Dwornik, A. Leśniak, Numerical modelling of the impact of flood wave cyclicality on the stability of levees, Abstract Book $3^{\text {th }}$ FLOODRisk, 3, 1-6 (2016)

17. J. Stanisz, Z. Pilecki, H. Woźniak, Wybrane zagadnienia numerycznej analizy stateczności osuwiska w Swoszowicach, Technika Poszukiwań Geologicznych. Geotermia, Zrównoważony Rozwój 2, 77-89 (2012)

18. M. Dyba, Z. Pilecki, Wpływ sposoby zawodnienia na ciśnienie porowe i naprężenie efektywne w obliczeniach numerycznych programem FLAC 2D, Przegląd Górniczy 7, 25-31 (2012)

19. P. Popielski, B. Smoliński, A. Kasprzak, Ocena stanu obiektów hydrotechnicznych na podstawie wyników interdyscyplinarnych programów badań $i$ symulacji numerycznych, Czasopismo Inżynierii Lądowej, Środowiska i Architektury 63, 25-32 (2016) 